\title{
Paradiplomacy of the Kurdistan Region After 2003: Present and Future
}

\author{
Dr. Dana Ali Salih (Assistant Professor) \\ Faculty of Law and Politics/ department of Political Science, University of Sulaimani/ Iraq \\ Bakhan Ako Najmalddin (Assistant Lecturer) \\ Faculty of Law and Politics/ department of Political Science, University of Sulaimani/ Iraq \\ Sulaimani Post Office-Iraq: P.O.Box 47-Sulaimani
}

\begin{abstract}
This research discusses the essential but sensitive subject of paradiplomacy in the Kurdistan Region of Iraq after 2003, with regard to the present and the future. It attempts to seek answers to the main question facing the Region regarding paradiplomacy as a means for achieving an independent state, and to extent the Kurdistan Region has used this mechanism successfully to achieve this aim. In order to answer this question, the study will focus on paradiplomacy in the region from 2003 until today, by examining various scenarios and to project Kurdistan Region's future. The conclusion is that the Kurdistan Region -with all comments- that is able to use paradiplomacy as an effective mechanism at both regional and international levels, and in this way, the KRG has taken a step closer to independence, but to achieve success in the future, all its departments of democracy must be strengthened and to become more powerful it must become more successful in paradiplomacy.
\end{abstract}

Keywords: Diplomacy, Independent state, Iraq, Kurdistan region, Paradiplomacy

\section{Introduction}

After the Second World War, and particularly in the 1960s, multilateral international regimes emerged in world politics, and non-state actors from the private sector, NGOs and academia increased their global influence (O’Neill, 2009). This reality was quickly depicted by scholars who were interested in the nature, the role and the impact of non-state actors in international relations; this activity is known as 'paradiplomacy' (Setzer, 2013). The term 'paradiplomacy' has been applied to the activities of sub-state governments seeking to pave the way for independence by preparing international opinion and seeking friends who might be prepared to recognize them at an early stage(Keating, 1990: 1-16).

Paradiplomacy is a relatively new phenomenon and subject in the study of international relations. It refers to what one could describe as a "foreign policy capacity" of sub-state entities, their participation, independent of their metropolitan state, in the international arena in pursuit of their own specific international interests. This is a conceptually and practically challenging development - conceptually because the discipline of international relations does not normally consider sub-state entities as subjects of international relations; and practically because a state's claim to external sovereignty, their unique right to engage with other players in the international arena, is, in a sense, hollowed out and perhaps fatally undermined if they have to share this essential prerogative of statelessness. That is to say, paradiplomacy, at least in its most developed form, needs to be reconceptualized through a theoretical linkage with sub-state or stateless nationalism (Ibid: 15).

The most directly political motivation is in regions with national aspirations or governed by parties seeking sovereign statehood. The most obvious example of this is the Kurdistan Region's effort to become an independent state, especially after the collapse of Saddam Hussein's regime in 2003.

Paradiplomacy can be a difficult subject to discuss, not least because there is sometimes an understandable reluctance to admit that one is engaging in it (Grydehoj, 2014). Moreover, until now, most research on paradiplomacy has been conducted on federal regions in the 'developed' world (Aldecoa \& Keating, 1990: 4-8), with relatively few systematic studies of the international relations of the Kurdistan Regional Government (KRG). This article builds on this literature, and, engaging with recently published works (Natali, 2010), argues that the involvement of the KRG in foreign relations, whilst once inhabiting the 'Gray' area of unrecognized states (Owtram, 2009) and quasi-states (Kolsto, 2006), is now more firmly consolidated into the activity of international relations of federal countries. The argument, initially advanced in earlier work (Sharif, 2015), encompasses the attitude of both international and regional powers. These geopolitical realities and superpower interests buttress the maintenance of the state of Iraq in a loose, decentralized form of federalism, which enables the Kurdistan Regional Government (KRG) to continue to develop politically and economically.

Unless there is a radical change in the structures of regional geopolitics or international powers, there will be a declaration of independence or a bid to secede from Iraq by the Kurdistan Region because there is a plausible basis by which the Kurdistan Region might hope to gain recognition of a declaration of independence either from the regional powers or a great power. In addition, the KRG benefits from the current situation of political stalemate (Natali, 2010). Nevertheless, it must be borne in mind that the Middle East is currently a fast 
changing environment, and the effects and implications of the Arab spring, the United States withdrawal from Iraq, the war in Syria, and emerging Islamic State of Iraq and al-Sham (ISIS) group is unlikely yet to be fully played out (Mohammed, 2013).

\section{Significance of the research}

Firstly, in terms of a theoretical framework, little research has been conducted on this topic; therefore, it requires further scientific study.

Secondly, contrary to the existence of a well-developed literature on paradiplomacy, there is a rather small and limited literature on the paradiplomacy of Kurdistan. In addition, the studies that have been conducted so far to date are more descriptive than theoretical. Furthermore, to date, there are few comprehensive studies that show how the paradiplomacy of Kurdistan has growth since 2003. Thus, this paper will address the various theories of international relations in order.

\section{The research aim}

To reach a deeper understanding of the structural determinants of Kurdistan's paradiplomacy, which will not only be capable of explaining the KRG's current foreign activities, but also of predicting future developments.

The third point is related to the Kurdistan Region, which is the main point of this research, as, on the one hand the Region is growing politically, economically and diplomatically; however, on the other hand, the Kurdistan Region is more stable in terms of security compare to other parts in Iraq. Therefore, discussing paradiplomacy of the Region in these situations requires further academic research.

The main aim of this research is to present an objective and academic study in the field of political science and diplomacy in general, and Kurdistan's decision making and diplomacy in particular, in order to achieve a clear, objective and academic vision for paradiplomacy, and its positive benefits. Paradiplomacy currently has the main role in strengthening the position of the KRG and in establishing a clear and hopeful future going forward.

\section{The research problematic}

The central research question of this paper is whether the Kurdistan Region is able to practise paradiplomacy effectively after 2003 and to strengthen its position to establish an independent state.

\section{The research hypothesis}

The Kurdistan Region after 2003 has achieved recognition as an important actor at both regional and international level through improving the processes of paradiplomacy that might ultimately lead to an independent state. Moreover, the Kurdistan Region's channels of paradiplomacy have become stronger and more active in moving closer to an independent state.

\section{The research methods}

To write an academic research, several methods have been used, such as the historical method, to explain the emergence of paradiplomacy in Kurdistan, the analytical method, to show how paradiplomacy affects the Kurdistan Region, the case study method, which specifically focuses on Kurdistan, and the future method, to predict the future of paradiplomacy in Kurdistan.

\section{The research structure}

The research highlights three essential chapters. Before elucidating the analytical framework of this study, the first chapter will delve deeply into the concept of sub-state diplomacy after which a brief explanation regarding the historical background of the Kurdistan Region until 2003 will be presented. The second chapter examines the case of the Kurdistan Region; it begins by discussing the growth of paradiplomacy in Kurdistan after 2003, followed by illustrating the increase in foreign representatives and consulates in the Region. Finally, the last chapter offers a brief discussion of the implications of paradiplomacy for achieving the goal of independence for Kurdistan.

\section{1: The theoretical framework and historical background}

\subsection{Concept and definition of paradiplomacy}

The objective of this chapter is to analyse the emergence of sub-national governments as international actors (referred to as sub-national governments engaging in paradiplomacy). To achieve its proposed objective, the chapter will delve deeply into the historical background, and elucidate the concept and definition of sub-state diplomacy.

The phenomenon of paradiplomacy is not new; for instance, the Quebec Government began to play a role in foreign affairs as early as the nineteenth century (Lachapelle \& Raquin, 2005: 40). However, the current 
era of paradiplomacy is the period extending after the Second World War. Consequently, a significant change occurred in the once exclusively interstate system that had occupied the foreign sphere since the 17 th century. While sovereign states remain the main players in this scenario, the acceleration of globalization and the development of regional integration processes have facilitated the existence of important new actors to a once international stage (Marinana, 2010).

Tracing the evolution of the concept, in 1986, Duchacek utilized the term 'regional microdiplomacy' or 'microdiplomacy' to illustrate regional relations across borders (e.g. The USA and Mexico, or the USA and Canada) (Duchacek, 1986). Following this work, in 1988, Latouche, Stevenson and Duchacek edited a book on 'perforated sovereignties' to discuss how and why states, cantons, provinces, and large municipalities increasingly seek access to technological information and sources of wealth. The subsequent contributions to the literature were given by Soldatos (1990) who proposed the term 'paradiplomacy' to identify the diverse forms of foreign and diplomatic activities undertaken by non-state actors, and by Brian Hocking in his book 'Localizing foreign policy' (Soldatos, 1990), Hocking and in an edited book entitled 'Foreign relations and federal states' (Hocking, 1993) . A few years later, another multi-authored book edited by Aldecoa Franciso and Michael Keating (1990) explored the reasons why regions 'go abroad' (Keating, 1990). In the 2000s, other collective published works continued advancing this argument. Lachapelle and Paquin discussed that paradiplomacy is being expanded as a result of globalization and the weakening of the nation-states (Lachapelle \& Paquin, 2005) In 2009, another book edited by Michelmann brings a comparative discussion on the constitutional powers that sub-units of federal governments require to conduct foreign activities, and a special issue of the Hague (Setzer, 2013).

In many of these works, there has been an ongoing semantic and conceptual confusion that arises when using the term paradiplomacy, constitutional diplomacy or sub-state diplomacy. The paper considers most of the terms as paradiplomacy. This is deemed necessary because of the semantic confusion that exists in the literature on sub-state diplomacy about what paradiplomacy or sub-state diplomacy actually is.

A genealogy of archaeological excavations of the historical traces of paradiplomacy is presented to elucidate the concept or term of paradiplomacy. The term 'paradiplomacy' first surfaced in the early 1980s to describe the foreign activities of federated constituencies in Canada and the USA. Panayotis Soldatos was the first scholar who attempted to invent a name to 'identify' this assembly of rather diverse forms of non-state diplomacy (Soldatos, 1990). For the first time, he coined 'paradiplomacy', an abbreviation of 'parallel diplomacy'. One could define this as 'the foreign policy of non-central governments' (Aldecoa \& Keating, 1990). Paradiplomacy was initially labeled 'identitary paradiplomacy' by Paquin, 'paradiplomacy of stateless nations' by Lecours and Moreno, or 'maximal paradiplomacy' by Philippart. The concept was later disseminated in the academic literature via the publication of Ivo Duchacek (who preferred the term 'micro-diplomacy') (Duchacek, 1990), 'intermestic' (Manning, 1977), 'multilayered diplomacy' (Hocking, 1993),'constituent diplomacy' (Kincaid, 1990), among other terms. However, archaeology of the phenomenon of paradiplomacy can reveal the utility of the word 'paradiplomacy', which continues to be the most commonly used in the literature on the subject. Some scholars, such as Brian Hocking, have a negative perspective of the term 'paradiplomacy' because it suggests an element of conflict between the national and sub-national policy-level, and implicitly presumes 'incompatible interests' (Criekemans, 2006: 3). Despite the divergences, all these terms share an interest in sub-national or noncentral governments' direct and indirect involvement in international relations (Setzer, 2013).

Alongside the term 'paradiplomacy', scholars have different viewpoints about the definition of paradiplomacy. According to Ivo Duchacek and Panayotis, who drafted the first definition to the term, the concept of paradiplomacy "refers to direct international activity by sub-national actors (federated units, regions, urban communities, cities) supporting, complementing, correcting, duplicating or challenging the nation-states' diplomacy" (Soldatos, 2004). Paquin makes the case that paradiplomacy comes into play when a sub-national government gives its representatives a mandate to negotiate with other international players (Corango, 1999). According to Tedford, "Considerable political activity is happening along the multiple frontiers between the local, provincial, federal, Aboriginal and international spheres of governance" (Ibid). In a later study, this time directly related to the issue of security, Noe Cornago defines paradiplomacy as "non-central government involvement in international relations through the establishment of permanent or ad hoc contacts with foreign, public or private entities, with the aim to promote socioeconomic or cultural issues, as well as any other foreign dimension of their constitutional competences" (Corango, 1999). In sum, Kaiser, drawing on the work of Michelmann (1990) and Aldecoa and Keating (1999), declares that paradiplomacy refers to the external relations of sub-national actors. He goes further to say that such relations can either be coordinated with and complementary to the activities of the central state level or they are pursued in conflict or concurrence with traditional "macro-diplomacy" (Vengroff \& Rich, 2004: 4-5). However, all authors more or less agree that a broad definition of paradiplomacy is the external activities of sub-national, regional entities or non-central government (Grydehoj, 2014).

The Journal of Diplomacy was devoted to the topic (Bursens \& Deforche, 2010). Among the 
contributions, Corango discusses that sub-state governments' activism is spreading rapidly across the world, to a point where it is possible to see a worldwide 'normalization of sub-state diplomacy' beyond the classic examples of Quebec (Corngo, 2010), the Basque Country or Flanders. For instance, Bueno da Silva collected examples of paradiplomatic activity in the UK, Spain, Canada, Germany, France, Italy, Japan, Austria and Belgium, as well as in India, Argentina, Mexico, China, Russia and South Africa (Setzer, 2013:39). However, this paper focuses on the Kurdistan Region as the case study because it has been very active in promoting its paradiplomacy as a stateless nation and seeking name recognition.

\subsection{Conceptual Framework for Paradiplomacy of the Kurdistan region}

The KRG has had a wide range of analytical labels applied to it. Harvey and Stansfield claim that "since the early 1960s, the predominantly ethnic Kurdish areas of Northern Iraq represented, at one time or another, an insurgent state, an autonomous region, an insurgent state/proxy and, from the 1990s onwards, a range of statelike forms, such as de facto state, de facto states (due to the division of the Kurdistan Region of Iraq following civil war) (Harvey \& Stansfield, 2011), an unrecognized state, a recognized unrecognized state, as well as a regional state of Federal Iraq" (Mohammed, 2013).

Using this framework, attention will now be given to its relevance to the Kurdistan region. The current status of the Kurdistan region grew from the Transitional Law for the Administration of Iraq (TAL) signed in March 2004, followed by the 2005 Iraqi permanent constitution, which recognized Kurdistan as a legal region of the Federal State of Iraq. Following the creation of the unified the Kurdistan Regional Government, in January 2006, a Department of Foreign Relations was formed, headed by Minister Falah Mustafa Bakir.

The increase in the paradiplomatic activity is represented by the offices of the KRG abroad and the presence of foreign diplomatic missions and international offices in the KRG. Currently, there are more than 30 consulates and commercial offices in Kurdistan (Ibid: 67-68).

\subsection{Historical background of the Kurdistan region until 2003}

The Kurds are the largest non-state nation living in their historic settlement area. After the World War I peace settlement and the Treaty of Severs (1920), hopes of Kurdish independent state were raised; however, in 1923, under the Treaty of Lausanne, the Kurds were given minority status in four countries, namely, Iraq, Iran, Syria and Turkey with smaller enclaves elsewhere in the region. Regarding Kurdistan in Iraq, even before the collapse of the Saddam regime the Kurds had more national rights in Iraq compared to other host countries. In 1931, previous Iraqi governments allowed the Kurdish language to be used in education; in 1958, Kurdish nationality was recognized, and in 1971, limited Kurdish autonomy was implemented under Baath Party rule (Katzman, 2010).

During the 1990s, United States- led containment of Iraq following the attack of Kuwait paved the way for Kurdish autonomy. After the Iraqi military suppressed an initial post-war Kurdish uprising, the United States and allied forces in mid-1991 instituted a 'no-fly zone' over the Kurdistan Region, protecting the Kurds from Iraqi military forces. Later in 1991, Kurdish leaders joined the Iraqi National Congress (INC), a US-backed opposition group, and allowed it to operate from Kurdistan territory. On May 19, 1992, the Kurdistan Region held elections for a 105-member provisional parliament. The Kurdistan Democratic Party (KDP) and the Patriotic Union of Kurdistan (PUK) each gained 50 seats. Without a clear winner in the concurrent presidential election, the two main parties agreed to joint rule. In October 1992, the Kurdish Parliament called for "the creation of a Federated State of Kurdistan in the liberated part of the country" but added that the Kurds remained committed to Iraq's territorial integrity. However, this caveat did not allay fears among Iraq's leaders that the Kurds would push for full independence; a concern shared by neighbouring countries with large Kurdish populations (Iran, Syria, and Turkey) (Ibid: 1-2).

In fact, since 1991, the entity that has emerged in Northern Iraq is an independent state in all but name. As Peter Galbraith, a long-time advocate of Kurdish national rights, purports, "The Kurds have established a real state within a state, with an administration that performs all governmental responsibilities, from education to law enforcement [and] militias [that] number 70,000 to 130,000". The Kurdistan Region, with a population of $5,472,436$ in 2015 (according to the Statistics Department in Kurdistan), which is larger than at least 50 percent United Nations member countries, has functioned without control from central government (International Crisis Group, 2003).

In 1994, the uneasy PUK-KDP power-sharing mechanism collapsed into armed conflicts over regional control and joint revenues. Thus, the Kurdish Regional Authority split into the PUK and KDP entities; nevertheless, the US spearheaded negotiations that ended in a September 1998 'Washington Declaration' between both parties. It was authorized when the Kurdish Parliament reconvened on October 5, 2002, by which time the Kurds were organizing for a likely US-led invasion of Iraq (Katzman, 2010: 2). From McDowall's viewpoint, "It was only the imminence of a US invasion of Iraq that compelled them actively to cooperate to present a united political and military stance" (McDowall, 2000). The Kurds have long struggled to control their own destiny. 
Through centuries of cyclical autonomy and oppression, finally, the Kurds of North Iraq have united and have seized an opportunity to secure a firm legal status of their de- facto country within a federal Iraq state after the Iraq war in 2003 (Kelly, 2010).

For over ten years prior to the 2003 war, the existence of the Kurdistan Region as a de facto state under American and British protection has further contributed to strengthening a Kurdish identity that is aware of its separateness from the Arabs in Iraq and of the vulnerability that comes with being a minority. Thus, from the beginning of the post-Saddam period, the Kurds have demanded guarantees for their economic, political, cultural and physical security as a group and as individuals (Wolff, 2010:3).

Kurdistan region's involvement in foreign affairs, also referred to as paradiplomacy, is not a new phenomenon. It can be traced back to the second half of the 20th century, particularly under the leadership of Mullah Mustafa Barzani, when he led the Kurdistan rebel movement and cultivated ties with Iran and the US in the 1970s. However, in 1991, Kurdistan paradiplomacy received a fillip when the region secured virtual autonomy following the US-led invasion of Iraq in 2003. Since the unification of the KRG in 2006, the Kurdistan Region's leaders have ushered in a new level of "promoting Kurdistan" on the world stage (elDessouki, 2015: 1).

Foreign affairs and diplomacy serve as a matter of survival. Even though the Kurdistan Region Government (KRG) enjoys empirical statehood, and the privileges of statehood, including sovereignty over a territory, an armed force, a population, and an autonomous government that conducts independent foreign policy, the KRG still lacks juridical statehood. This means that its diplomatic carders and leaders must constantly reassert the Region on the international stage (Mansour, 2015: 2).

\section{2: Growing Paradiplomacy of the Kurdistan Region after 2003}

Since the toppling of Saddam's regime in 2003, the Kurdistan Region has gained more autonomy from the Baghdad government and has been active in reconstructing the country. Consequently, the Kurdistan Region can be considered one of the success stories of the Middle East. In explaining the development of paradiplomacy in Kurdistan, it is necessary that particular attention is paid to the constitutional and political frameworks in demonstrating the growth of paradiplomacy in Kurdistan after 2003.

\subsection{Paradiplomacy of Kurdistan in terms of the constitutional and political frameworks}

In order to clearly understand the role of paradiplomacy in Kurdistan the research will examine both the constitutional and the political frameworks in the following sections.

2.1.1 The Constitutional Framework

To understand the external relations within a particular federal country, the constitutional stipulation of that federation is one of the starting-points. As for the legal provision to implement paradiplomacy, most Kurdish leaders concur that the status of the KRG is constitutionally guaranteed and entrenched. In addition, they declare that the KRG has been granted legitimate powers to implement international relations but not to formulate foreign affairs. Moreover, regarding the constitutional restrictions, all Kurdish professionals in foreign affairs stress that the KRG implements international relations without breaching Iraqi sovereignty and without overstepping the limits of the exclusive authority of the Federal government. When speaking of the constitutional framework, Azad Barwari, Deputy Prime Minister of Kurdistan Regional Government, states, "It is right that formulating foreign policy and diplomatic representation of Iraq are included within the exclusive authority of the Federal government, but, according to the Article 121/4 in the Iraqi constitution. Offices for the regions and governorates shall be established in embassies and diplomatic missions, in order to follow cultural, social, and developmental affairs, which means that the regions and governorates have rights to establish offices in embassies and participate in diplomatic missions in order to follow cultural, social, and developmental affairs" (Barwari, 2015). What is more, the Kurdistan Region's representative to the UK makes the same point about this Article and adds, "In the Kurdistan Regional Government there is an order (No. 143 on 25th of January 2009) issued regarding the Department of Foreign Relations. Consequently, these are the two main legislative umbrellas under which we exist. The KRG's representations abroad existed before the Iraqi constitution" (Abdul Rahman, 2010).

On October 15 2005, the Kurds supported the constitution referendum because it met their most important demands. The constitution not only retained sub-national Kurdish autonomy but also included the Kurds' insistence on "federalism"-de-facto or formal "regions", each with its own regional government. The constitution identifies the three Kurdish provinces of Irbil, Sulaimani, and Dohuk as a legal "region" (Article 113) - the KRG- with the power to amend the application of national laws not specifically under the national government purview, to establish embassies abroad, and to maintain internal security forces (Article 117). In September 2007, the Senate endorsed the federalism concept for Iraq in an amendment to the FY2008 defence authorization bill.

The Iraqi Constitution of 2005 appears to answer the question regarding the role of the Kurdistan region 
in foreign affairs. The constitution stresses that international relations, including "formulating foreign policy and diplomatic representation and negotiating, signing and ratifying international treaties and agreements", are exclusive to the federal government. Other matters related to international relations identified by the constitution as 'exclusively federal' comprise home affairs, defence, maritime and land ports, border crossings, civil aviation and water sources from outside Iraq, fiscal, economic and monetary policy. According to Article 110, the federal government shall have exclusive authorities in the following matters: Formulating foreign policy and diplomatic representation; negotiating, signing, and ratifying international treaties and agreements; negotiating, signing, and ratifying debt policies and formulating foreign sovereign economic and trade policy (Kurdistan Region Presidency, 2015).

Whatever the constitution announces, it is not easy for the Kurdistan Parliament to avoid debating major international issues. In addition, the constitution provides the Kurdistan Region with jurisdiction on implementing international agreements and treaties. This must necessarily and logically carry with it the right to sign and negotiate those agreements and treaties, since the process of negotiation cannot realistically be separated from internal implementation. Hence, the Kurdistan Region is the sole federal region explicitly mentioned in the constitution and is currently the only one, possessing an international character that can refuse to implement, in legal terms, any international agreement it finds not to its satisfaction (El-Dessouki, 2015). Moreover, the constitution gives Kurdistan joint jurisdiction on several matters with international implications, including environmental policy, immigration, electrical power, regional customs, public health, education and development policies, and the development of oil and gas (Ibid).

In order to discharge all the competence that it enjoys under the constitution in an efficient and effective way, the Region should be given more power to participate in foreign affairs. Few governmental actions are devoid of foreign impact in today's gradually more interdependent globe. Consequently, it occurs arbitrary and highly impractical to refuse Kurdistan region any international dimension for the exercise of its power (Ibid: 5).

Another important point is made by Talib Rasheed Yadgar, General Director of the Presidential Diwan at the Kurdistan Region Presidency, in respect of the ability to implement foreign affairs by the federal regions. As stated by Yadgar, a federal region's involvement in international relations depends on the legal personality of the region. This means that the regions possess the legal personality in two ways: first, through the efficiency of the region itself to implement the policies, and second, through the constitutional framework. He believes that since Article 117 of the Iraqi constitution stipulates that Kurdistan is a federal region, it can practise foreign relations and be involved in international relations. Moreover, in the Iraqi constitution, Article 110 identifies the exclusive powers of the federal government. All the paragraphs of this Article do not mention the implementation of international relations. Therefore, he argues that Article 115 identifies that what is not stipulated in the exclusive authorities of the federal government belongs to the regional authorities and are not among the exclusive powers of the central government. Furthermore, Article121/4 gives the regions the right to establish offices in diplomatic missions and embassies in order to follow social, cultural, and developmental affairs. According to Yadgar, the Kurdistan Region's paradiplomacy does not contravene or breach Iraqi sovereignty or overstep the limits of federal exclusive authorities (Yadgar, 2010). In addition, the head of KRG representation in Baghdad, Mohammed Ihsan, confirms, "In terms of exercising international relations, according to the Articles of the Iraqi constitution, so far what the KRG has done is legal without breaching Iraq sovereignty" but in specific areas. Furthermore, Brendan O'Leary stipulated that the Iraqi constitution wholly fulfils the Kurds' long-held demand, emphasizing autonomy for Kurdistan and democracy for Iraq (Ihsan, 2010). The KRG has the right to have offices to represent the region in all consulates and embassies in all matters within the Kurdistan National Assembly's powers (Mohammed, 2013). According to Article 142, "The new constitution of Iraq recognizes the Kurdistan National Assembly, Government and Region, and all of the Region's laws and contracts since 1992. It grants the Kurdistan National Assembly complete autonomy in all but the very small number of exclusive and limited powers of the Federal government, and the right to nullify or modify any Federal legislation where powers are shared between the federal and regional governments".

As far as the constitutional framework is concerned, the KRG implements paradiplomacy according to the interpretations of the Articles of the Iraqi constitution. The wording of some of them allows room for interpretations or readings of the legality of Kurdistan Regional Government's international relations.

According to these constitutional Articles, the Kurdistan Region has a significant role in practising paradiplomacy, particularly according to Article $121 / 4$ in social, economic and development matters. Furthermore, in the case of a dispute between regional government and central government, preference is given to the Kurdistan Region. This is an important entrance for activities in paradiplomacy.

2.1.2 The Political Framework

Both before and after the 2003 overthrow of Saddam's regime, the Kurds have continued to be the most pro-US group in Iraq. Since then, the Kurds welcomed the US invasion of Iraq and have cooperated officially with the US both militarily and politically. The Kurds have sought US support for their position in their various disputes with the other groups in Iraq, and have endeavoured to ensure that the planned December 2011 end to US 
military involvement does not cause the US to abandon Iraq, and the Kurds. Even though the Kurds welcomed the US decision to oust Saddam's military, there was practically no combat in Kurdistan during Operation Iraqi Freedom (OIF), the US-led war that began on March 19, 2003, and collapsed Saddam's regime by April 9, 2003 (Katzman, 2010: 2).

For the first time ever the Kurds entered the post-Saddam national political arena on an equal footing with Iraq's Arabs by participating in a US-led occupation administration (Coalition Provisional Authority, CPA). Holding seats on a 25-person advisory "Iraq Governing Council (IGC)", appointed in July 2003, were Jalal Talabani, Masoud Barzani, and three independent Kurds. In the transitional government that assumed sovereignty on June 28, 2004, a top Barzani aide, Hoshyar Zebari, became Foreign Minister. On March 8, 2004 , this government achieved, under a "Transitional Administrative Law" (TAL), a provisional constitution that laid out a political transition process and preserved the Kurds' autonomous "Kurdistan Regional Government" and its power to alter the application of some national laws (Ibid: 3 ).

On January 30, 2005, the Kurdistan Region fully participated in the Iraqi elections, which included provincial council elections nationwide and elections for the Kurdistan National Assembly (KNA), in addition to national elections for an interim government. On June 12, 2005, the Kurdistan National Assembly (KNA, the separate parliament of the KRG) selected Masoud Barzani as "President of Kurdistan". This reflected President Barzani's strategy of shoring up his regional base in the KRG rather than focusing on the Baghdad government (Ibid).

In the political framework, we must focus on the relationship between central government and regional government. Since the collapse of Saddam Hussein's regime, for over a decade the Kurds have succeeded in carving out a degree of de facto political independence. They have been developing the early trappings of democracy and enjoying its economic benefits. And promotes the questions: What is next for the Kurdistan region? (International Crisis Group, 2003:1).

The Kurdistan Region has been relatively prosperous and peaceful since the collapse of Saddam Hussein's regime. In addition, the Region has Kurdish members of parliament, ministers, and the current president is also a Kurd. Even if the Kurdistan Region is unable to become a federal country, at least the KRG's policy can ensure that the Kurdistan region remains a powerful federal region within a federal Iraq (Mohammed, 2013).

As mentioned above, the Kurds generally have viewed participation in post-Saddam politics in Baghdad as enhancing Kurdish interests. In contemplating their future both outside and inside Iraq, the Kurdish leaders know they will have to contend with several influential actors who may either thwart or assist their ambitions. Among these are Turkey and the United States, as well as Iran and Syria. Iran, which has its own interests to protect the Kurdistan Region, is also cautiously looking at developments from the sidelines (Katzman, 2010).

In post-Saddam Iraq, the Kurdish Peshmerga (the Kurdish regional militia) has fought alongside the coalition troops in Northern Iraq, sustaining many casualties and impressing the US government with their zeal. Consequently, when the US government began to attempt to establish democracy in Iraq, it regularly looked to the Kurdish leaders for cooperation and advice.

Kurdistan's autonomy is the one scenario that would almost definitely meet with autonomic agreement from any government coming to power in Baghdad (Ibid). However, de facto independence is not easily or automatically turned into formal statehood. The Kurdish state needs to engender good relations with its neighbours in order to allow for the transhipment and trade of goods essential for the Region's independent economic development and infrastructure rehabilitation. In addition, it would need international guarantees and recognition, as well as expertise in marking frontiers, raising a professional class and training its security forces. In other words, the trappings of a state without the substance would make a Kurdish state riskily dependent on its most powerful neighbours, and a potential vassal state, to Turkey, Iraq or Iran. Turkey, in particular, has vociferously opposed any Kurdish move towards declaring independence. It is worried not only about the emergence of a Kurdish state, but that such a country would have the goal to expand, targeting south eastern Turkey with its mainly Kurdish inhabitants and important water resources. Similarly, Iran has openly warned against any Kurdish moves towards an independent state (Harvey \& Stansfield, 2011).

It is clear that the Kurdistan Region requires expansion in both constitutional and political frameworks so that it can strengthen its position within Iraq and the region, and practise a kind of paradiplomacy.

\subsection{The rise of paradiplomacy of the Kurdistan region after 2003}

After the invasion of Iraq by the US in 2003, many analysts have focused on the various aspects of Kurdish activities. These aspects include the exchange of representations and visits/missions with a number of foreign countries, the participation in the activities of conferences and international organizations, and the establishment of a department to handle international relations. Moreover, Kurdistan is involved in various kinds of interactions with foreign countries and regions outside Iraq.

The Kurdistan region possesses an actual 'paradiplomatic service', complete with its own minister, a 
corps of officials specializing in international relations, and a network of foreign representatives. In 2006, the Department of Foreign Relations (DFR) was structured on the same model as the federal Ministry of Foreign Affairs. It consists of seven directorates (of KRG Offices Abroad, of Protocol and Delegations, of Administration and Finance, of Legal Affairs, of International Organizations, and of International Relations in the Region), each with at least two sections. The head of the department has a ministerial rank and, to all intents and purposes, is the foreign minister of the Region (EL-Dessouki, 2015).

The DFR holds monthly meetings for foreign consuls, United Nations representatives and officials of other international organizations, updating them on security, political and economic related developments in Kurdistan. In addition, the department is responsible for developing Kurdistan's relations with other foreign countries as well as for maintaining contacts with Kurdish interests outside Iraq. It ensures that Kurdistan participates in international activities and events and that the KRG's message reaches the outside world. The DFR also manages a network of representational offices abroad; it facilitates the smooth running of international organizations and the missions of foreign representatives in Kurdistan, and organizes the visits of business and political delegations to the region (Ibid). Since the KRG is a non-state actor and is not a sovereign state, it uses the tools of negotiation, economic strategies, and diplomacy to pursue its own body of international relations' goals.

Another significant mechanism to institutionalize the KRG's paradiplomacy is entering into international agreements. Kurdistan leaders recognize that international agreements would allow the region to assert its international capacity and its personality to enter into and initiate formal relations with other international players. Furthermore, entering into international agreements is a way of promoting the region interests (International Crisis Group, 2003). Since 2006, the Kurdistan Region has made agreements with several countries, including South Korea, Germany, France, UAE, Jordan, Qatar, Egypt, Lebanon, Iran and Turkey, as well as multinational companies and international organizations (such as UNESCO). These agreements pertain to several fields of trade, tourism, infrastructure, education, agriculture, transport, oil and gas. Moreover, the KRG insists on having its role in negotiations of international agreements signed by the federal government (Ibid: 12).

Furthermore, the KRG hosts diplomatic visits and missions of various countries and also has its representative offices in many foreign states around the world. The KRG also has offices of representation abroad. Moreover, these offices have been opened according to the KRG's order and are legal.

The participation of regional governments in foreign affairs is essential and beneficial for Kurdistan and Iraq as well. For example, Tissot asserts that both the federal governments and the regional governments benefit when the regional governments are involved in foreign relations. In respect of the Kurdistan Region's link to international politics, he declares, "It is good for Kurdistan and it is good for Iraq. And, I hope more regions in Iraq, for example, the Basra region, will be able to have relations with other countries and other regions, but they have to respect the Constitution and not breach the sovereignty of Iraq" (Tissot, 2010). The participation of the regional governments in foreign affairs is beneficial to the democratic development of a federal state.

Analysis of most of the diplomatic efforts made by the Kurdistan leaders reveals the importance of a clear vision in developing external relations. In particular, since 2003, the KRG has developed special relations with the European countries, the UK, the US, Iran, Turkey, and some Arab countries.

After 2003, the KRG witnessed the development of its capabilities and the steady social and economic progress in the region; thus, it became essential to consider preparing the first comprehensive strategic plan for development in the region, regardless of the difficulties that were expected in the organization and implementation of the plan on both regional and international levels (Kurdistan Regional Government Ministry of Planning, 2012).

2.2.1 Consulates and foreign offices in the Kurdistan Region

At home, the KRG now hosts about 33 general consulates, embassy offices, consular offices, commercial offices and honorary consuls. General consulates (the Islamic Republic of Iran, the Russian Federation, the Republic of France, the Republic of Turkey, the Unites States of America, the Hashemite Kingdom of Jordan, the Arab Republic of Egypt, the Palestinian National Authority, the Czech Republic, the Republic of Hungary, the Republic of China, the Kingdom of the Netherlands, the State of Kuwait and the British Consulate General). Embassy offices (the Republic of Korea, the Kingdom of Sweden and the Republic of Poland). Consular offices (the Republic of Italy, The United Arab Emirates, Romania, the Republic of Austria, the Republic of Bulgaria and the Hellenic Republic (Greece)). Commercial offices (Japan International Cooperation Agency (JICA), Korean International Cooperation Agency (KOICA), UNAMI Regional Representation Office and ICRC Regional Office. Honorary consuls (the Kingdom of Spain, Japan, the Kingdom of Denmark, the Republic of Slovakia and the Federal Republic of Brazil (Department of Foreign Relations, 2015).

It is clear that five permanent states in the United Nations have consulates and offices in Kurdistan, which is a strong point for KRG paradiplomacy.

2.2.2 KRG offices abroad

The Iraqi constitution allows Kurdistan to establish and maintain representative offices related to their areas of 
jurisdiction, in order to pursue international social, cultural, and development affairs.

The Department of Foreign Relations - Institutionalizing External Relations, headed by Minister Falah Mustafa Bakir, the KRG's Department of Foreign Relations in Erbil, has made significant gains in reaching out to countries overseas (El-Dessouki, 2015: 11).

These diplomatic missions have functions that sometimes extend beyond the borders of the host state and cover other states. For instance, the KRG's office in Russia not only deals with the Kurdish-Russian relations but also handles relations with Commonwealth countries. The range of activities of the KRG office in Spain extends to the whole Iberian Peninsula; also the Kurdish office activities in Sweden extend to all Scandinavian countries. In the same way, the KRG's diplomatic mission in America covers Canada as well. In addition, its trade missions and representation abroad, Kurdistan organizes its own international trade conference (Ibid: 13).

2.2.3 Increase in companies and diplomatic delegations

To fulfil the function of advocating and promoting the Kurdistan Region and its views and interests worldwide, Kurdistan officials have led scores of political, cultural, and commercial mission/visits abroad every year and have been received as official visitors. In 2010, for instance, Kurdistan's President, prime ministers, ministers and senior officials conducted more than 28 visits abroad, which took them to North America, Europe and the Middle East. In the same year, President Masoud Barzani made over 14 visits and missions to the US, Germany, France, Italy, Austria, Turkey, Saudi Arabia, Jordan, Lebanon, Egypt and the Arab League. He was received as a head of state in many of these countries. Other noteworthy developments in this regard have been the official visit of Dr. Barham Salih to Egypt, Morocco, the Arab League, the UAE and the UK in 2009 (El-Dessouki, 2015: 11).

Another step toward improving diplomatic relations with other countries is the visits made by the President of Kurdistan to various countries. In April 2010, the visit of the President, Massoud Barzani, to both the Lebanon and the Kingdom of Saudi Arabia marked a significant development in international relations in the region. During Barzani's visit to Lebanon, he was welcomed at the airport by the Lebanese Prime Minister and the Iraqi Ambassador to Beirut. The reception accorded to Barzani in Beirut was similar to that befitting a head of state. In Saudi Arabia, King Salman bin Abdulaziz al-Saud, the Saudi monarch, decorated him with the King Abdul Aziz Medal of the First Degree, which is given only to heads of state. Following the historic visit by the Turkish Foreign Minister to Erbil in October 2009, and the opening of a Turkish consulate in the Kurdistan region in 11 March, 2010, in the same year Turkey invited Barzani for an official visit to the country. Additionally, in January 2009, Barzani visited the US, as the province enjoys a 'strategic alliance' with the United States. During his visit, he met the US President, Barak Obama, as well as the Secretary of State, the Vice-President and others (The Emirates Centre for Strategic Studies and Research, 2010). More recently, on 21 November, 2014, Barzani met with senior Turkish officials in Ankara where they discussed strengthening relations and increasing cooperation in the fight against ISIS. This was the first time a Turkish PM had received Kurdistan region's officials under the Kurdish flag at the meeting. Barzani's visit to Turkeytook place a week after his meeting with top United Arab Emirates (UAE) officials in Abu Dhabi and the Saudi King, Salman bin Abdulaziz al-Saud, in Riyadh. The top official leaders welcomed Barzani officially as the president of an independent country, all of which means that Kurdistan has come of age diplomatically and politically.

In addition, the KRG received several high-ranking foreign officials from different parts of the globe. In 2013, Kurdistan received approximately 175 foreign visitors, including ministers, ambassadors and officials from overseas regions, high-ranking executives, and senior officials from several international organizations. These visitors came from different parts of the world, including North America, Europe, Australia, Asia, and the Middle East. The most prominent among them were the US Vice-President, the Polish Prime Minister, The Foreign and Defence Ministers from Britain, the US, Turkey, United Arab Emirates and Belgium, and senior Russian officials, representatives from the EU, the Special Representative of the UN Secretary General, and the Secretary General of the Arab League. Moreover, scores of trade delegations have been flooding into Kurdistan to explore investment opportunities in the region and to sign trade agreements with its government (Mansour, 2015).

These exchange visits seek to market Kurdistan as a model for the rest of the country and a gateway to Iraq. They ensure, among other things, international recognition of the region's current quasi-statehood. The KRG model is based on democracy, stability and prosperity, as well as the ease of doing business, women's rights, tolerance and a civil society (Ibid).

Another point which makes the position of Kurdistan stronger is the oil contracts between the KRG and foreign countries. Since 2003, the KRG and the central government have been in a dispute over control of the country's oil resources. The Kurds' oil policy seems to be gaining more international attention recently. In 2003, the Kurds signed their first deal with Turkey's Pet Oil. After that, it claimed the 2005 Iraqi Constitution allowed it to develop new oil fields. It then went ahead and created its own Natural Resources Ministry in May 2006, and after negotiations over a new oil and gas law broke down in parliament, it passed its own oil legislation in August 2007. It has also offered production sharing agreements that provide greater profits for companies, which 
have led to several dozen contracts being signed, mostly for exploration and drilling work (Kurd Daily, 2012). In addition, KRG oil exports have increased rapidly; according to the current report by the KRG Ministry of Natural Resources, in January 2016, the KRG exported 18,656,131 barrels of crude oil (an average of 601,811 barrels per day) in the month of January through the Kurdistan pipeline network to the port of Ceyhan in Turkey. Of this amount, fields operated by the KRG contributed 14,016,489 barrels $(452,145$ bpd on average), while fields operated by the North Oil Company (NOC) contributed 4,639,642 barrels (an average of 149,666). Due to circumstances beyond the KRG's control, during January there was one day of downtime for the export pipeline.

Cumulatively, there was approximately one day of downtime in January due to circumstances beyond the KRG's control. The figures presented in this table show the daily averages considering the actual number of days the pipeline was online, which was about 30 days.

The Middle East is facing a prolonged war between the different sides of political Islam including ISIS. However, the rise of ISIS has strengthened the Kurds' territorial and political position and has aided their push for independence. The disintegration of the Iraqi army enabled the Peshmerga to take control of almost all the disputed Kurdish-populated territory previously under the control of the central government, including Kirkuk. It is now virtually inconceivable that the KRG will relinquish these gains. At present, the Kurdish Peshmerga is the only effective ground force fighting ISIS, which has gained them enormous international support. In theory the Kurds are now in a position to organize a referendum themselves and use it as the basis for a unilateral declaration of independence.

Since the war waged by ISIS war is considered a war against the international community, many countries have announced that the world needs to stand with the Peshmerga, which makes Kurdistan appear a powerful region in the international arena. As Iraq crumbles under increasing pressure from ISIS, the Kurdistan Region is well placed to stand together with the international community, which understands that moving towards closer security and commercial cooperation with the Kurdistan Region is in everyone's best interests. Furthermore, the Kurdistan Region can also inspire and help democratization in countries where they reside (Sharif, 2015).

Since the Peshmarga has engaged in the war against ISIS, many countries have confirmed their foreign delegates' visits to the Kurdistan region, particularly their defence ministers, due to ongoing commitments in the fight against ISIS and increased coordination with the Peshmerga. Thus, it is important to highlight the role of foreign countries in supporting the Peshmerga forces. The increase in the number of visits of delegates from foreign countries to the Kurdistan Region is a positive reflection of the Region's political stance toward the world; furthermore, such foreign cooperation increases diplomatic relationships and may lead to the establishment of an independent state of Kurdistan in the future.

After the collapse of Saddam's regime, the Kurdistan Region was able to rewrite the constitution and holds a significant position in the region. As a result, more than 33 countries, among them five permanent members of the UN Security Council, now have offices in the Region, and many diplomatic agreements have been signed with them. In addition, according to official data, visits by foreign delegations to Erbil have increased dramatically; and the Kurdistan Region's delegations have treated them formally. This is evidence that the KRG is able to improve its paradiplomacy going forward.

\section{3: The future of Kurdistan's paradiplomacy}

To understand the future of paradiplomacy in Kurdistan, the research considers two different scenarios; the scenario of continuous and the scenario of change.

The diplomatic approach is vital for the KRG because of one key reality: their autonomy, and ultimately their statehood, can only emerge if they receive approval regionally and internationally. The Kurdish leaders believe that no matter how much empirical sovereignty they acquire or how much they endeavour to build their nascent state, without the backing of the international community, their efforts will be undermined (Mansour, 2015).

Today, the Kurdish leaders have constructed a narrative that diplomacy is the only way the Kurdistan Region can move away from the age-old adage "no friends but the mountains" (Ibid) Falah Mustafa, the KRG's head of foreign relations, stated that the Kurdistan Region has spent millions of dollars on diplomacy, more than it has spent on any other area of operation. This includes diplomatic communications as well as training its diplomats in protocol and etiquette, "....because we are tired of brothers, what we want are friends with regional and international countries" (Ibid). The Kurdistan Region hopes to achieve this friendship with other countries by diplomacy, especially through increasing economic ties and maintaining security and stability in the Region. For further explanation, this chapter discusses the future implications of the KRG's foreign policy strategy.

\subsection{The scenario of continuous}

This scenario, based on the hypothesis that the KRG will continue to develop and strengthen its position in Iraq specifically, and in the Region generally, which has led it to develop its paradiplomacy, however the region still 
remains a part of Iraq and it is as yet unable to establish an independent state.

3.1.1 Internal obstacles

Since 2003, the Kurdistan Region has been playing the 'independence card', with local politicians and commentators increasingly airing their views publically on the subject. Although the Kurdistan government has made significant gains and is eager to publicize them, the reality is much more complex. The KRG faces many challenges that could undermine the gains the KRG has made thus far (Khalil, 2009). There are several domestic, regional and international issues that threaten both the image and the reality of the KRG as the stable hub of Iraq, namely, the oil and gas problem, lack of economic independence, and the disputed territories and Article 140.

These issues are likely to determine the future of diplomacy in Kurdistan. If the KRG cannot surmount these obstacles, it is hard to imagine they will be able to achieve a prosperous future. Furthermore, their failure could have profound internal consequences for Kurdistan and the rest of the region (O'Leary \& Bateman, 2008). 3.1.1.1 Oil and gas problem

Regarding domestic issues, the first major challenge for the future of the KRG stems from the controversy over Iraq's oil law. The hydrocarbon problem may seem small compared to the larger challenges facing Iraq, but the oil law has become a key battle within the much bigger struggle over the powers of the central government versus the KRG. In addition, the oil law will be a significant element in defining the nature of federalism in Iraq and this, in turn, may determine the course of the KRG (Khalil, 2009).

The hydrocarbon law has the potential to re-emerge as a problem in at least two ways. Firstly, the agreement between central government and the KRG provides the Kurdistan government with 17 percent of all hydrocarbon revenues (based on supposed population distribution). Nevertheless, central government claims that this overstates the population of the Kurdistan Region and disagrees with the principle that revenues should be distributed purely by population in the regions. Secondly, the Iraq constitution is deliberately unclear about revenues from newly developed fields. The KRG has repeatedly asserted that they would continue to abide by the current revenue-sharing terms even for new fields, but the central government has its doubt (Ibid).

As long as the oil issue remains unresolved, the KRG's future remains in doubt. More precisely, the indecision has profound consequences for the future of Kurdistan's economic development, political stability and diplomatic progress.

3.1.1.2 Lack of economic independence

Beside the Kurdistan-Baghdad issues, the KRG faces many internal challenges. Even for the Kurdish inhabitants themselves, the main question about an independent Kurdistan is a matter of economics.

The reality is that the Kurdistan Region is landlocked; it is dependent upon selling its own natural resources and importing consumables in exchange. Not having good relations with neighbouring countries is simply not an option for Kurdistan (Zulal, 2012). In the short term, the Kurdistan Region would still struggle to generate as much income as central government sends them. Putting the required infrastructure in place would take time and would need the consent of neighbouring countries including Iran and Turkey (Ibid).

Even though Kurdistan has other income opportunities and income streams, and the promise of a hydrocarbon pipeline to Turkey offers a lifeline, in the short term, this income would not be sufficient to pay salaries in the bloated public sector or to invest in rebuilding the infrastructure, all of which would eventually lead to many political and social problems (Ibid).

As a result, even though many Kurds yearn for an independent state, if the state's finances dwindled, causing budget cuts, unemployment and a reduction in living standards, their views may well change. Whatever other disagreements they may have, almost all Kurdish politicians can see this how this situation would be extremely unpopular.

3.1.1.3 Disputed territories and Article 140

The disputed territories of Northern Iraq, or disputed internal Kurdish-Iraqi boundaries, are regions defined by Article 140 of the Constitution of Iraq in 2005 as being abused during the Baath Party rule in Iraq. Most of these regions had previously been inhabited by non-Arab minorities, most notably Kurds, and were later Arabized by transferring and settling Arab tribes in those territories. The disputed areas have been a core concern for Arabs and Kurds, especially since the US invasion in Iraq. The Kurds gained areas to the south of Iraqi Kurdistan after the US-led invasion in 2003, to regain the land they considered historically theirs. Today, in addition to the four governorates of Kurdistan, the Kurds now control parts of Kirkuk Governorate, Salah ad Din Governorate, Diyala Governorate, and Nineveh Governorate, which are also claimed by the Iraqi government; conversely, the Iraqi government controls parts of those four provinces, some parts of which are also claimed by the Kurds.

Most importantly, under Iraq's constitution of 2005, the political status of the "governorate" (province) of Kirkuk, and other disputed territories, was scheduled to be formally resolved by the end of December 2007. The prospective referendum affecting the status of Kirkuk governorate was, by agreement, postponed for six months, until the summer of 2008. The KRG and all the Kurds within it ardently want to unify with the relevant disputed areas, either by agreement or referendum. The constitutional obligation to fulfil Article 140 remains a constitutional imperative, and the people of the Kurdistan Region are able to block any proposed amendment to 
Iraq's constitution, which would modify Article 140 (O'Leary, 2008). Furthermore, Article 140 outlines a series of steps that should be taken in order to resolve who exactly the disputed areas belong to. These are: firstly, normalization - a return of the Kurds and other residents displaced by Arabization, followed by a census taken to determine the demographic makeup of the province's population, and then finally, a referendum to determine the status of disputed territories. Clearly, whether an area is home to mainly Kurds or mainly Arabs will have an effect on who can lay claim to the area. It is certain that if the problem of the disputed territories is not solved between central government and the KRG it could present an obstacle to improving paradiplomacy in the Kurdistan region.

\subsubsection{Regional obstacles}

In terms of regional level, if Kurdistan became an independent state, it would be a small state, surrounded by far larger, less friendly states in the region including Turkey, Iran and Syria. Those neighbouring countries are the most likely nations to oppose the idea, as, if Iraq lost its Kurdish areas, Turkey would lose 15- 20 present of its territory, Iran would lose 4-5 present, and Syria would lose 5-10 present of its territory, including some oil fields in the north east (World Review, 2013).

Kurdistan and Turkey have historical antipathies (Turkey is still fighting a battle against the Kurdish population within its own borders). Turkey is fearful that the establishment of an independent Kurdish state in Iraq would lead to demands for autonomy for its own 13 million Kurds (Dahi, 2015). Similarly, Iran opposes the declaration of an independent Kurdish state. Tehran is increasingly nervous about a potential bid by the Kurdistan region for independence. Firstly, an independent Kurdish state next door could incite Iran's own Kurdish minority, setting a dangerous precedent in the multi-ethnic country. Secondly, the two countries most likely to have the most leverage over an independent Kurdistan would be Israel and Turkey, Iran's regional rivals. From Iran's perspective, a Kurdish blowback inside Iran and an Israeli and Turkish geopolitical alliance at Iran's expense must be thwarted (Vatanka, 2014).

It is clear that beside internal obstacles, regional obstacles are the main reason to predict that paradiplomacy in the Kurdistan Region may decrease and may prevent further moves towards diplomacy.

3.1.3 International obstacles

Regarding the international level, with the current situation in Iraq in sight, Kurdish leaders can see that the KRG is gradually advancing toward independence and believe that the US should strongly support the KRG's independence as the best way to contribute to peace and security in the region, especially in a post Saddam Iraq. However, on May 4 2015, the Kurdistan President, Masoud Barzani, met with the US President, Barak Obama, and Vice President, Joe Biden, in the White House to discuss continuing US support for the Kurdistan Region and Baghdad in the struggle against the Islamic State group. Many also believe that Barzani sought US support for early Kurdish independence. If so, then Barzani came away disappointed, as the US continues to believe that a united Iraq is the best option (Gunter, 2015).

Most observers feel that premature Kurdish independence would be perceived as destroying Iraq and would be opposed by not only the US, but the international community. Furthermore, the question of Kurdish independence has always troubled the surrounding countries and would change the balance of power in the region. Thus, almost all countries have never wanted a Kurdish state (Zulal, 2012).

Therefore, should the Kurdistan region secede, it is not clear whether the US and the international community would recognize the would-be country as a fully fledged nation state (Ibid: 141).

In brief, it is possible that the Kurdistan Region is sufficiently politically mature to become independent but the region is not ready for such a step in economic, political or military terms. If Kurdistan advocates independence, they face economic hardship as well as regional isolation, a loss of influence in Iraq and increased dependence on the goodwill of both Turkey and Iran, all of which would lead to crippling paradiplomacy in the region.

\subsection{The scenario of change}

This scenario is based on the hypothesis that the Kurdistan Region, because of its significant position, can improve its paradiplomacy as a mechanism that might lead to establishing an independent state in the future.

Since the uprising in 1991, and the establishment of a semi-autonomous entity in the Kurdistan Region, the Kurdish leaders realized that diplomacy is vital for its survival and is a guarantee towards achieving an independent state (Tissot, 2010).

The Kurdistan Region's international affairs during this period have concentrated on developing a strong national security agenda, opening up the region for investors, enhancing economic diplomacy, taking optimum advantage of its abundant natural resources and using them as a tool for diplomacy, and as a means of applying leverage on neighbouring countries that have historically been hostile to the Kurds (Ibid).

Since the Kurdish uprising, the Kurdistan Regional Government and the Kurdistan Parliament were formed as well as the Kurdistan Region Presidency. The Kurdistan Regional Government (KRG) was formed in 1992 by the Kurdistan National Assembly, the first democratically elected parliament in Kurdistan (and in Iraq) 
following the no-fly zone designed to protect the Kurdistan region from the violence of Iraq's former Ba'ath regime. The KRG developed experience and expertise throughout successive cabinets, especially after the fall of the former regime in 2003. In 2006, two separate KRG cabinets unified to form the 5th Cabinet, led by Prime Minister Nechirvan Barzani. The 5th Cabinet embarked upon a number of unprecedented projects and policies that were not possible in previous years. These included the construction of international airports, a proactive oil and gas policy, reconstruction of the Kurdistan Region's infrastructure, the promotion of relations with members of the international community, and greater funding for social and economic projects within the Region. The 6th Cabinet, led by Dr. Barham Salih, built upon the successes of the 5th Cabinet, promoting a number of important domestic issues related to housing, higher education, and government transparency. The 7th Cabinet has achieved some key strategic successes, none more important than developments in the field of oil and gas and a rapid influx of foreign investment (Kurdistan Parliament, 2016).

Kurdistan's central legislative body is the all-member Kurdistan Parliament, a unicameral body of lawmakers. The President appoints the Prime Minister from the largest bloc to form a government. The cabinet is then approved by the Kurdistan Parliament.

The Iraqi Kurdistan Parliament (IKP), is the parliament of Iraqi Kurdistan. The IKP is made up of representatives from the various parties, lists, elected to serve every four years by the inhabitants of the provinces of Iraqi Kurdistan currently governed by the KRG. The IKP is a 111-member unicameral body in which 11 seats are reserved for non-Kurdish minority communities in the Iraqi Kurdistan region. The election, held on 19 May 1992, was the first free and fair parliamentary election in the history of Iraq. Voter turnout was very high and the elections were deemed free, fair and democratic by international observers. After decades of dictatorship, the people in Kurdistan were able to vote for their representatives. During the fourth term of the Kurdistan Parliament, a total of 45 sessions were held; 3 of them for initiating Parliamentary issues, 2 were unusual sessions and 40 were usual ones. In the past working year of the Parliament (2014), the Parliament made 9 laws and 32 resolutions in different fields. During the same period of time, the Kurdistan Parliament has had readings for 112 law projects and resolutions, and has submitted them to the committees in charge of researching and preparing reports for the Parliament (Ibid).

Regarding the presidency, the Kurdistan Parliament established the Kurdistan Region Presidency (KRP) as an institution in 2005. The President of the Kurdistan region has the highest executive authority, and is elected by secret ballot in a popular vote every four years. Masoud Barzani, the current President, was elected as the Kurdistan Region's first president on 31 January 2005 by the Kurdistan Parliament, and re-elected by the people of the Kurdistan Region in July 2009, with $70 \%$ of the vote. The Deputy President is Kosrat Rasul Ali. The President's secretariat, the Diwan, is headed by Chief of Staff, Dr. Fuad Hussein. The term of the current presidency was extended in 2013 by parliamentary decree. The President represents the people of Kurdistan at national and international levels, and oversees relations and coordination between the Region and the Iraqi federal authorities. He also represents the people of Kurdistan at Iraq's Political Council for National Security and in negotiations and consultations with the government of Iraq. The President is responsible for approving the KRG Prime Minister's special appointments and promotions, and for ratifying all laws passed by the Kurdistan Parliament. He has the power to return any law passed by the Parliament, once only, for further debate and amendment (Kurdistan Region Presidency, 2015).

3.2.1 The KRG's international affairs tools, economic diplomacy and the use of natural resources as a tool The Kurdistan Region has been attempting to lay the foundations for a stable policy environment and create an environment conducive for investment; furthermore, the KRG is slowly making progress by forging alliances. Attempting to attract foreign investment, the Kurdistan Region's aim has always been to strengthen multilateral partnerships and to create strong bilateral relations with neighbouring countries (Zulal, 2010: 144-145).

The Kurdistan Region has experienced an economic boom since 2003. This region, which is relatively prosperous and secure, has become of increasing interest to international companies for investment. In addition, the KRG has made large investments in infrastructure, buildings, tourism and energy. Over forty percent of the Iraqi oil stock is located in the Kurdistan Region. There is sufficient oil in the Region to place Kurdistan in the Top 10 oil countries. Thus, there is a great demand for medium and small enterprises in Kurdistan. The strategy of the Kurdistan Regional Government is to expand the above mentioned sectors over the coming years, resulting in job creation (SPARK, 2015).

A US Geological Survey reported that Kurdistan could hold more than 45 billion barrels of oil plus it has an estimated 60 tcf (trillion cubic feet) of gas reserves, which would place Kurdistan in the world's Top 10 countries with the largest hydrocarbon reserves. Therefore, the Kurdistan Region now has the potential to become an important and reliable source of energy, which could lead to considerable economic development in the region. The KRG has been doing its utmost to use this newfound wealth to its advantage and to form alliances regionally and internationally. Natural resources will play a leading role in the Kurdistan Region's foreign and economic policies; for instance, oil has already been used to form alliances with Turkey, as is discussed below (Zulal, 2010). 
The KRG has abundant natural resources and other valuable minerals. Consequently, adopting investorfriendly strategies to attract the skills and experience needed, in addition to looking outward, has made Kurdistan an attractive place for investment and has earned it many allies around the globe. In 2011 alone, more than 430 foreign companies registered in the KRG, a rise of 30 percent year on year. Furthermore, according to statistics released by the KRG investment board, the region has attracted US\$16.2 billion in investment in the past five years (Ibid).

Trade has been thriving, but the trade balance is largely tipped in favour of Iran and Turkey. However, by strengthening economic ties with these countries, the KRG intends to turn its traditionally hostile adversaries into allies and to increase soft power in the region. For instance, Turkish companies are thought to make up 55 percent of all the foreign companies operating in Kurdistan, and annual trade is estimated at US\$4 billion. Turkey is the main or largest trading partner. Turkey's energy minister, Taner Yıldız, at a major energy conference in Erbil, spoke about the essential trade partnership between Turkey and the KRG, which he announced accounts for over 70 percent of the US\$11 billion that Turkey trades annually with Iraq (Shamas \& Chomani, 2014). It is clear that the KRG has used its economic position as a tool for building its relations with foreign countries and developing its paradiplomacy.

3.2.2 Security and Stability

In recent times, the Kurdistan Region has been called 'the other Iraq' and security has been one of the major priorities of the KRG. Striving to attract foreign investment, the authorities understand the significance of stability. While the rest of Iraq has been, and is still in large parts of the country, plagued by disorder and violence, the Kurdistan Region has remained secure and stable. Although the de facto state has experienced many social, economic and political crises in relations with its neighbouring countries, the KRG has managed to consolidate and maintain its sovereignty. Therefore, the Kurdistan Region's survival strategy can be seen as a success story (Council on Foreign Relations, 2015).

Although the Kurdistan Region is transitioning towards an independent state, Kurdistan is neither at the initial stage of forming independence nor at the end of the process for declaring independence. The road toward statehood requires much hard work, preparation at home, diplomatic efforts abroad, and a strategic plan to address legitimate concerns (Shamas \& Chomani, 2014). In brief, the more successful the foreign policy of the Kurdistan Region is, the better the chance of moving toward becoming an independent state.

\section{Conclusion}

Paradiplomacy is inherently a pluralistic activity involving social and economic actors as well as governments, and its success often hinges on the ability to involve these.

This research focused on the paradiplomacy of regional governments and particularly examined the case of the Kurdistan Region's involvement in international affairs since 2003, analysing its capability to enter into diplomatic and foreign relations with regions and states, and the tools, motives and objectives for its paradiplomacy. The collapse of Saddam's regime in April 2003, and the designation of the Kurdistan Region as a federal region in the Iraqi constitution ushered in an era of unprecedented opportunity and prosperity for Iraqi Kurdistan; in terms of international relations, a new chapter in the Kurds' history was opened. The Kurdistan Region was given an opportunity to control their own destiny as never before in their turbulent history. In addition, since 2003, the Kurdistan Regional Government has been promoting ties with countries all over the world through its paradiplomacy.

The Kurds in Iraq are a large, heterogeneous region, non-state people; they are settled in a compact area but they straddle state boundaries. As a minority, they have suffered high levels of persecution and discrimination throughout the existence of Iraq as an independent state, and were practically asked to reintegrate into a post-Saddam Iraq after enjoying over a decade of quasi-independence and relative political stability. In order for the Kurds to contribute to stability and peace at the local, state and regional levels, there need to be in place arrangements for territorial and non-territorial self-governance, for power sharing at the central and local level, and for cross-border institutions and para-diplomatic competences. Despondently, the only well-developed arrangement is that for the territorial self-governance of the Kurdistan region in Iraq. Comparative experience from a wide range of cases elsewhere suggests that this is unlikely to be a sustainable situation in the longer term. This raises the question of the nature of alternative and additional arrangements that should be put in place.

Domestic structural contexts play an important role in explaining and shaping Kurdistan's paradiplomacy. Although the Iraqi Constitution makes foreign affairs an exclusive domain of the central government, it still leaves some ambiguities as regards the international roles of the Kurdistan region. This situation allows Kurdish leaders to claim their right to be involved in international affairs. Most importantly, Kurdish leaders have been bypassing constitutional strictures concerning international involvement of the regions. The high degree of autonomy the region enjoys has enabled it to be active and to wield substantive influence more directly in foreign affairs. The confrontational relationship between Erbil and Baghdad does not prevent the former from getting involved in foreign affairs. In reality, one of the major motivations for the 
Kurdistan Region to develop external relations and use foreign policy as a tool is to gain economic independence from Baghdad and position Erbil as a major player in the regional equation.

Furthermore, Kurdistan is using paradiplomacy as a mechanism to promote its constitutional status, and enlarge its regional autonomy. It is utilizing its foreign contacts to pressure or bargain with Baghdad for constitutional or institutional changes that recognize Kurdish interests, namely the "fair" distribution of oil revenues, the flexible federal system in Iraq, and the implementation of Article 140 of the constitution. Another major motive behind Kurdistan's drive to establish stronger external links is the desire to assert and enlarge its virtual autonomy vis-à-vis the central government and to achieve maximum control over economic resources of the region, especially oil and gas. Some experts consider paradiplomacy as a Kurdish strategy to gain international recognition for the 'semi-state' status that the Region already enjoys. For them, the Region seeks to achieve the benefits of independence as far as possible without caring too much about the official recognition of independence. For other analysts, however, Kurdish leaders are using their high-level involvement on their own. Not surprisingly, Baghdad is making every effort to contain international affairs as a means for the Kurdistan Region to secede from Iraq and to form an independent state by means of Kurdish international activity, but this has further spurred the KRG's involvement in foreign affairs.

The Kurdistan Region, as a non-secessionist region, executes paradiplomacy without breaching Iraqi sovereignty. The activities of the KRG are similar to those found in other federal countries. The actions are: permanent representations in foreign countries, trade missions, participation in international conferences and other events, as well as conclusion of international agreements and participation in joint international projects. The research revealed that the KRG employs tools, such as diplomacy, economic instruments, and negotiation, in implementing paradiplomatic activities to pursue its own body of foreign affairs objectives, which are guided by its political, economic, social, cultural, and developmental motivations.

Therefore, the Kurdistan Region has the rationale, and its case can be seen as an example of paradiplomacy based on the objectives (motivations) of international activities. Since 2003, the KRG's diplomatic efforts have reaped success and arguably put this region of Iraq in a stronger position than other Iraqi groups, by giving it stronger leverage in the international community. The KRG has plans to secede from the Iraqi federal state and implements all the external activities to gain support for an independent state. Therefore, the practice of paradiplomacy by Kurdistan as a federal region does mean an intention to secede from the Iraqi federal state.

The independent Kurdistan state requires much hard work alongside addressing the risks and challenges associated with the 'disputed territories', and the relationship between Erbil and Baghdad; clearly, the Kurdish Autonomous Region faces important internal challenges if it is to create an enduring peace. These are linked to the process of social and political normalization in the region, after decades of organized violence by the Saddam regime and after years of de facto autonomy in the exclusion area established in 1991, which included the outbreak of an internal, armed conflict. Furthermore, opposing the declaration of an independent Kurdish state by neighbouring countries and some in the international community makes the idea of Kurdistan state more difficult to realize.

The research contributes to the literature on the subject by providing hypotheses to be tested empirically or confronted with other case studies. In closing, this trend of sub-national governments participating in international security affairs is related to the empowerment of local actors and multi-track conflict prevention. It is an important and challenging research frontier waiting to be explored further by the academia.

\section{References}

(1) Abdul Rahman, B.S. (2010) Interview with the Herish M. Khalil on 18 April 2010, Erbil.

(2) Aldecoa, F. \& Keating, M. (1990) Regional \& Federal Studies 9 (1), 4-8.

(3) Barwari, D. (2015) Opposition demand is step back for KRG democracy. Available at: http://rudaw.net/english/kurdistan/2406201 (Accessed: 2/10/2015).

(4) Bursens, P. \& Deforche, J. (2010) Going beyond paradiplomacy? Adding historical institutionalism to account for regional foreign policy competences. The Hague Journal of Diplomacy, 5, 151-171.

(5) Corango, N. (1999) Diplomacy and paradiplomacy in the redefinition of international security: dimensions of conflict and cooperation. In Francisco Aldecoa \& Michael Keating (Eds.), Paradiplomacy in action: the foreign relations of subnational governments (pp. 40-57). London: Frank Cass.

(6) Cornago, N. (2010) On the normalization of sub-state diplomacy. The Hague Journal of Diplomacy, 5 (12), pp. 11-36.

(7) Council on Foreign Relations (2015) The Time of the Kurds. Available at: http://www.cfr.org/middle-eastand-north-africa/time-kurds/p36547?cid=otr-marketing-use-Kurds InfoGuide\#! (Accessed: 20/10/2015).

(8) Criekemans, D. (2006) How Subnational entities try to develōp their own 'Paradiplomacy' the case of Flanders (1993-2005). Belgium: University of Antwerp.

(9) Dahi, N. (2015) NATO Member Turkey Afraid of Kurdish Independence More than Threat of ISIS. 
Available at: http://theantimedia.org/turkey-afraid-of-kurdish-independence-more-than-isis

(Accessed: 9/9/2015)

(10) Department of Foreign Relations (2015). Available at: http://dfr.gov.krd (Accessed: 1/8/2015).

(11) Duchacek, Ivo D. (1986) Multicommunal and bicommunal polities and their international relations. In Ivo D. Duchacek, Daniel Latouche \& Garth Stevenson (Eds.), Perforated sovereignties and international relations: trans-sovereign contacts of subnational governments (pp.3-28). Connecticut: Greenwood Press.

(12) Duchacek, Ivo D. (1990) perforated sovereignties: towards a typology of new actors in international relations. In Hans J. Michelmann \& Panayotis Soldatos (Eds.), Federalism and international relations: the role of subnational units (pp. 1-33). Oxford: Clarendon Press.

(13) El-Dessouki, A. (2015) Structural Contexts and Paradiplomacy of Iraqi Kurdistan. Available at: http://www.feps.edu.eg/ar/publications/nahda/vol13/issue2/Ayman\%20desouky.pd (Accessed: 11/7/2015).

(14) Grydehoj, A. (2014) Goals, Capabilities, and Instruments of Paradiplomacy. Brussels: Centre Maurits Coppieters.

(15) Gunter, M. (2015) Possible Iraqi Kurdistan independence. Available at: http://ekurd.net/possible-iraqikurdistan-independence-2015-05-2 (Accessed: 9/9/2015).

(16) Harvey, J. and Stansfield, G., (2011) "Theorizing Unrecognized States: Sovereignty, Secessionism and Political Economy", Caspersen/Stansfield 2011: 11-26.

(17) Hocking, B. (1993) Foreign Relations and Federal States. Leicester: Leicester University Press. http://carnegie-mec.org/2015/06/29/how-kurds-helped-draw-united-states-back-to-iraq/ib6 (Accessed: $3 / 8 / 2015)$.

(18) Ihsan, M., Interview with Herish M. Khalil on 8 April 2010, Erbil.

(19) International Crisis Group (2003) War in Iraq: What's Next for the Kurds?. Available at: http://www.crisisgroup.org/ /media/Files/Middle\%20East\%20North\%20Africa/Iraq\%20Syria\%20Lebanon/ Iraq/War\%20In\%20Iraq\%20Whats\%20Next\%20For\%20The\%20Kurds.pd (Accessed: 3/8/2015).

(20) Katzman, K. (2010) The Kurds in Post-Saddam Iraq. CRS Report for Congress.

(21) Keating, M. Regions and international affairs: Motives, opportunities and strategies (1990) Regional \& Federal studies, 9 (1), pp. 1-16.

(22) Kelly, M. (2010) The Kurdish Regional Constitutional within the Framework of the Iraqi Federal Constitution: A Struggle for Sovereignty, Oil, Ethnic, Identity, and the Prospects for a Reverse Supremacy Clause. Penn State Law Review, 114 (3), pp. 707-771.

(23) Khalil, L. (2009) Stability in Iraqi Kurdistan: Reality or Mirage?. The SABAN CENTER for MIDDLE EAST POLICY.

(24) Kincaid, J., (1990) Constituent diplomacy in federal politics and the nation-state: conflict and co-operation. In Hans J. Michelman \& Panayotis Soldatos (Eds.), Federalism and international relations: the role of subnational units (pp. 54-75). Oxford: Clarendon Press.

(25) Kolsto, P. (2006) "The Sustainability and Future of Unrecognized Ouasi-States", Journal of Peace Research, 43(6): 723-740.

(26) Kurd Daily (2012) Why Turkey Wants Kurdish Oil. Available at: http://www.hurriyetdailynews.com/whyturkey-wants-kurdish-oil.aspx?pageID=449\&nID=36389\&NewsCatID=403 (Accessed: 12/2/2016).

(27) Kurdistan Parliament (2016). Available at: http://perleman.org/Default.aspx

(Accessed: 15/2/2016)

(28) Kurdistan Region Presidency (2015). Available at: http://www.presidency.krd/english/contact.asp (Accessed: 2/8/2015).

(29) Kurdistan Regional Government Ministry of Planning (2012) Regional Development Strategy for Kurdistan http://www.mop.krg.org/resources/Strategic\%20Plan/PDF/Regional\%20Development\%20Strategy\%20for \%20Kurdistan\%20Region\%202013-2017.pd (Accessed: 3/8/2015).

(30) Lachapelle, G. and Paquin, S. (2005) Mastering globalization new sub-states' governance and strategies. London and New York: Routledge.

(31) Manning, B. (1977) The Congress, the executive and intermestic affairs. Foreign Affairs, 55 (2).

(32) Mansour, R. (2015) Diplomacy for Survival. Available at: http://www.iraqstudies.com/iraq3.pd (Accessed: $13 / 7 / 2015)$.

(33) Marinana (2010) Outlooks for the legal framing of Paradiplomacy: the case of Brazil. Brasil: Federal Governance a graduate journal.

(34) McDowall, D. (2000) A Modern History of the Kurds. London: I.B. Tauris [Chapter 13: Subjects of the Shi'i Republic] p.22.

(35) Michelmann, H. (1990) Conclusion. In Hans J. Michelmann \& Panayotis Soldatos (Eds.), Federalism and International Relations: The Role of Subnational Units. Oxford: Clarendon Press.

(36) Mohammed, A. (2013) The Politics of Iraqi Kurdistan: Towards Federalism or Secession?. Available at: 
http://www.canberra.edu.au/researchrepository/file/3bee44d0-f162-8598-ad64033aa44dd1e3/1/introductory pages.pd (Accessed: 6/7/2015).

(37) Natali, D. (2010) The Kurdish Quasi-State: Development and Dependency in Post-Gulf War Iraq. New York: Syracuse University Press.

(38) O'Leary, B \& Bateman, D. (2008) Article 140: Iraq's Constitution, Kirkuk and the Disputed Territories. Available at: http://www.kncna.org/docs/pdf_files/oleary_paper.pd (Accessed: 10/2/2016)

(39) O'Leary, B. (2008) "The logics of power-sharing, consociation and pluralist federations". In settling selfdetermination disputes: complex power-sharing in theory and practice. M.Weller and B. Metzger. Dordrecht: Martinus Nijhoff Publishers.

(40) O'Neill, K. (2009) The environment and international relations. Cambridge: Cambridge University Press.

(41) Owtram, F. (2009) "The foreign policy of the Kurdistan Regional Government in Comparative Perspective", Presentation to the Centre for Kurdish Studies Conference, University of Exeter.

(42) Sharif, S. M. (2015) An Analysis of Kurdistan Region of Iraq Diplomacy and Foreign Policy objectives 2003-2013. Available at: file://C:/Users/GooGle\%20Show/Downloads/PHD-Thesis-Dr.-Sardar-SharifKRI-paradiplomacy-and-foreign-policy\%20(1).pdf (Accessed: 1/4/2016).

(43) Setzer, J. (2013) Environment Paradiplomacy: the engagement of the Brazilin state of Sao Paulo in international environmental relations. London: The London School of Economics and Political Science.

(44) Shamas, S. and Chomani, K. (2014) Kurdistan's transition towards independence. Available at: http://kurdishpolicy.org/2014/07/31/kurdistans-transition-towards-independence (Accessed: 4/8/2015).

(45) Soldatos, P. (1990) "An Explanatory Framework for the Study of Federal States as Foreign Policy Actors", H. Michelmann; P. Soldatos (eds), Federalism and International Relations: The Role of Subnational Units, Oxford: 34-53.

(46) SPARK (2015) Iraq/Kurdistan. Available at: https://www.google.iq/url?url=http://www.sparkonline.org/region/kurdistaniraq/\&rct $=\mathrm{j} \& \mathrm{q}=\&$ esrc $=\mathrm{s} \& \mathrm{sa}=\mathrm{U} \& \mathrm{ved}=0 \mathrm{CBwQFjAAahUKEwjq3eSey5THAhXr}$ n3IKHYJAASo\&usg=AFQjCNHsuRW-4X1VtQRmfA85wp2ExSSAu (Accessed: 6/8/2015).

(47) The Emirates Centre for Strategic Studies and Research (2010) Growing Foreign Ties of Iraqi Kurdistan. Available http://www.ecssr.ac.ae/ECSSR/print/ft.jsp?lang=en\&ftId=/FeatureTopic/ECSSR/FeatureTopic_1289.xml (Accessed: 13/3/2016).

(48) Tissot, F. (2010) International Relations: The Foreign Relations of the Kurdistan Regional Government (2003-2010). http://www.academia.edu/11966397/Paradiplomacy_of_Regional_Governments_in_International_Relations The_Foreign_Relations_of_the_Kurdistan_Regional_Government_2003_2010_(A- Accessed: 5/1/2016)

(49) Tissot, F., Interview with Herish M. Khalil on 11 April 2010, Erbil.

(50) Vatanka, A. (2014) Why Iran Fears an Independent Kurdistan. Available at: http://nationalinterest.org/feature/why-iran-fears-independent-kurdistan-1095 (Accessed: 9/9/2015).

(51) Vengroff, R. and Rich, J. (2004) Paradiplomacy and the Canadian Provinces. Available at: http://ciber.business.uconn.edu/wp-content/uploads/sites/967/2014/11/paradiplomacycanadianprovinces.pd (Accessed: 1/8/2015).

(52) Wolff, S. (2010) The relationships between states and non-state peoples: A comparative view of the Kurds in Iraq. Available at: http://www.stefanwolff.com/files/kurds-in-iraq.pd (Accessed: 17/7/2015).

(53) World Review (2013) Kurdish independence: what it could mean for the Middle East. Available at: http://www.worldreview.info/content/kurdish-independence-what-it-could-mean-middle-eas (Accessed: 9/9/2015).

(54) Yadgar, T.R., Interview with Herish M. Khalil on 7 April 2010, Erbil.

(55) Zulal, S. (2012) How likely is an independent Kurdistan?. Available at: http://www.niqash.org/en/articles/politics/3087 (Accessed: 12/9/2015). 